\title{
EKSPERIMEN PADA STRUKTUR PILE CAP TIGA TIANG DENGAN METODE STRUT AND TIE MODEL
}

\author{
Maulana Agung Sedayu ${ }^{1}$, Djoko Sulistyo ${ }^{1}$, dan Akhmad Aminullah ${ }^{1}$ \\ ${ }^{1}$ Departemen Teknik Sipil dan Lingkungan, Fakultas Teknik, Universitas Gadjah Mada, Yogyakarta \\ Email: maulana.agung.s@mail.ugm.ac.id
}

\begin{abstract}
In general, the design of the pile cap structure still uses conventional method assuming all regions experience linear strain. However, in reality the strain distribution in the cross section of the structure is not always linear so that a rational analysis method is needed with the assumption that is close to the actual condition using the strut and tie model method. This study aims to determine the behavior of crack pattern in the pile cap designed using the strut and tie model method (SNI 2847:2013 Appendix A) compared to conventional methods (SNI 2847:2013 Article 15). The specimen is the pile cap with three-piles and concentrated load, each of which has three methods. Loading is a static load that is channeled through a column located centric towards the structure of the pile cap. The results show that: the entire test object based on the two methods have flexural crack pattern. The average load capacity of the first crack $\left(P_{c r}\right)$ on the specimen was designed using the strut and tie model and the conventional method were $239.0 \mathrm{kN}$ and $193.7 \mathrm{kN}$. The average of crack width on the specimen using the strut and tie model and the conventional method were $0.68 \mathrm{~mm}$ and $3.88 \mathrm{~mm}$.
\end{abstract}

Keywords: crack pattern, pile cap, three-piles, strut and tie model

\begin{abstract}
ABSTRAK
Pada umumnya perancangan struktur pile cap masih menggunakan metode konvensional dengan asumsi semua daerah mengalami regangan linier. Akan tetapi pada kenyataannya distribusi regangan pada penampang struktur tidak selalu linier sehingga diperlukan suatu metode analisis yang rasional dengan asumsi yang mendekati kondisi sebenarnya yaitu menggunakan metode strut and tie model. Penelitian ini bertujuan untuk mengetahui perilaku pola retak pada pile cap yang dirancang dengan metode strut and tie model (SNI 2847:2013 Lampiran A) dibandingkan dengan metode konvensional (SNI 2847:2013 Pasal 15). Pada setiap metode terdiri dari tiga buah benda uji berupa pile cap tiga tiang dengan beban sentris. Pembebanan berupa beban statis yang disalurkan melalui kolom yang terletak sentris terhadap struktur pile cap. Hasil pengujian menunjukkan bahwa keseluruhan benda uji berdasarkan kedua metode mempunyai pola retak lentur (flexural crack). Untuk rata-rata kapasitas beban saat retak pertama $\left(P_{c r}\right)$ pada benda uji yang dirancang menggunakan metode strut and tie model dan metode konvensional adalah sebesar 239,0 kN dan 193,7 kN. Kemudian rata-rata lebar retak pada benda uji menggunakan metode strut and tie model dan metode konvensional adalah sebesar 0,68 $\mathrm{mm}$ dan 3,88 $\mathrm{mm}$.
\end{abstract}

Kata kunci: pola retak, pile cap, tiga tiang, strut and tie model 


\section{PENDAHULUAN}

Pile cap merupakan pelat penutup tiang pada fondasi dalam sebuah bangunan yang berfungsi menyebarkan beban dari kolom ke tiang-tiang, kemudian disalurkan ke dalam tanah. Pada struktur ini terjadi konsentrasi tegangan yang besar karena pada titik pertemuan pile cap dengan kolom terdapat gaya-gaya terpusat. Selain itu juga terjadi perubahan penampang pada bagian kolom, pile cap, dan tiang. Dengan demikian dapat dikatakan bahwa struktur pile cap ini mengalami distribusi regangan non-linier yang disebabkan karena discontinuitas geometri dan statika sehingga struktur tersebut harus didasarkan pada teori plastisitas.

Pada sebuah bangunan pile cap merupakan struktur yang sangat vital karena berpengaruh terhadap kekuatan dan kestabilan dari suatu bangunan tersebut. Namun dalam perancangannya sering dianggap memiliki distribusi regangan yang linier yang didekati dengan hypotesa bernoulli. Pendekatan pada perancangan tersebut dapat dikatakan belum akurat dikarenakan pile cap mengalami distribusi regangan non-linier, sehingga diperlukan suatu metode analisis yang lebih mendekati perilaku struktur pile cap pada kondisi sebenarnya.

Hardjasaputra dan Tumilar (2002) menjelaskan bahwa strut and tie model adalah suatu metode perancangan struktur beton dengan membagi struktur menjadi daerah $B$ dan daerah $D$ yang didasarkan pada asumsi bahwa aliran gaya-gaya (load path) sebagai transfer gaya yang terjadi pada struktur beton bertulang pada kondisi retak dari sumber pembebanan sampai tumpuan.

Schlaich, Schafer, dan Jennewein (1982 1993) membagi daerah pada struktur beton menjadi daerah B dan daerah D. Daerah B adalah daerah dimana hypotesa bernoulli berlaku yaitu daerah dengan distribusi regangan yang linier. Sedangkan daerah D adalah daerah yang mengalami distribusi regangan non-linier yang disebabkan oleh discontinuitas statika, geometri, atau kombinasi dari keduanya.

Shah dkk (2011) dalam "Analysis and Design of Disturbed Regions in Concrete Structures" menunjukkan bahwa hasil pengujian pile cap yang dirancang menggunakan metode strut and tie model hampir terjadi kegagalan geser karena mengalami retak diagonal.

Raj dan Airin (2017) dalam "Experimental and Analytical Investigation of Strut and Tie Model Method of Pile Cap" menunjukkan bahwa rasio kekuatan pile cap secara model analitis maupun model eksperimen pada metode strut and tie model mempunyai nilai yang paling kecil sehingga dapat disimpulkan bahwa metode strut and tie model merupakan metode perancangan struktur pile cap dengan dua tiang yang paling ekonomis.

Permasalahan pada struktur pile cap yang mengalami regangan non-linier yang disebabkan discontinuitas statika dan geometri dapat diselesaikan dengan menggunakan metode strut and tie model karena dianggap sebagai metode yang paling rasional, konsisten, sederhana dan akurat. Oleh karena itu pada penelitian ini akan dilakukan pengujian eksperimen di laboratorium untuk mengetahui pola retak pada pile cap tiga tiang dengan beban sentris menggunakan metode strut and tie model (SNI 2847:2013 Lampiran A) dibandingkan dengan menggunakan metode konvensional (SNI 2847:2013 Pasal 15). 


\section{METODE}

Benda uji berupa pile cap tiga tiang dengan beban sentris yang dirancang dengan metode strut and tie model (SNI 2847:2013 Lampiran A) dan metode konvensional (SNI 2847:2013 Pasal 15). Perancangan benda uji pile cap tersebut diambil dari beban sebuah bangunan lantai tiga sebesar 2500 kN (kombinasi $P_{D L}$ dan $P_{L L}$ ). Adapun bentuk pemodelan strut and tie model yang digunakan dalam penelitian ini dapat dilihat pada Gambar 1.

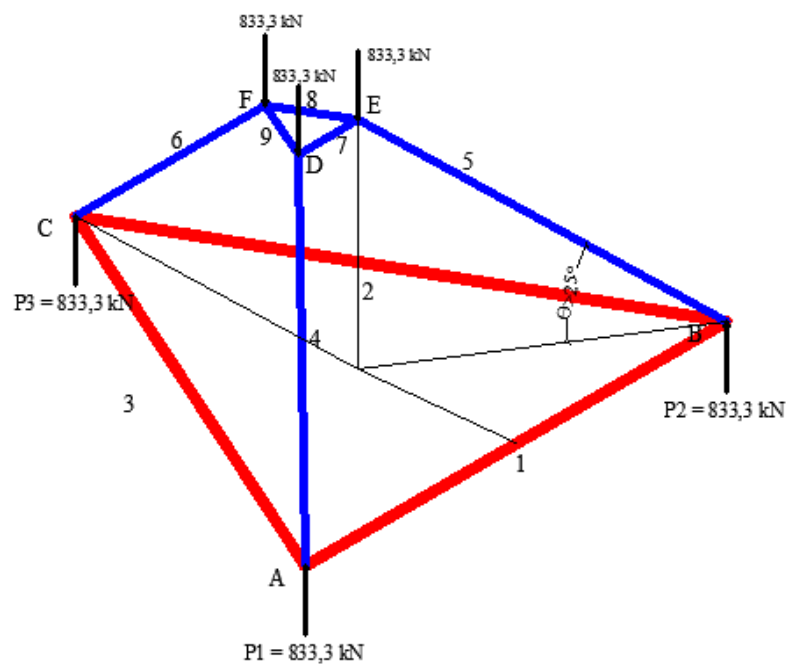

Gambar 1. Bentuk Permodelan Strut and Tie Model

Selanjutnya hasil perancangan benda uji pile cap tersebut diskala $1: 2,5$ dengan menggunakan Teori Buckingham (Suhendro, 2000). Benda uji berupa tiga buah pile cap yang dirancang menggunakan metode strut and tie model diberi notasi PC-SS-3P-1, PC-SS-3P-2, dan

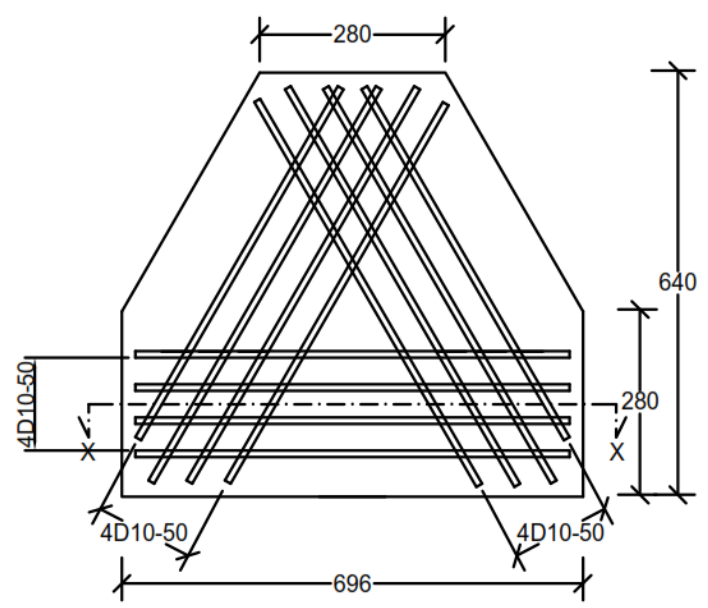

(a)
PC-SS-3P-3. Sedangkan benda uji lainnya berupa tiga buah pile cap yang dirancang menggunakan metode konvensional diberi notasi PC-KS-3P-1, PC-KS-3P-2, dan PCKS-3P-3. Adapun detail benda uji pile cap dan posisi pemasangan strain gauge dilihat pada Gambar 2 s.d 5

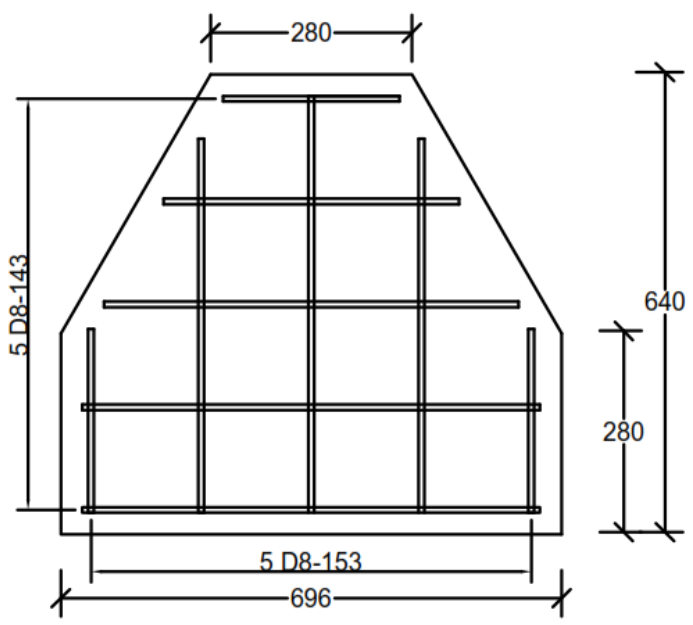

(b) 
Eksperimen pada Struktur ... (Maulana/ hal 31-43)
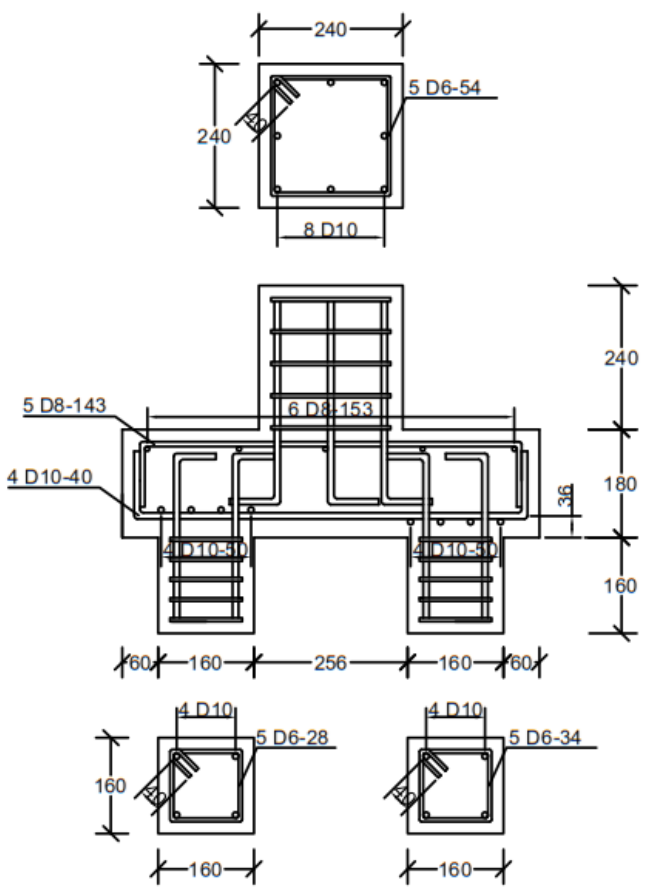

(c)

Gambar 2. Detail Benda Uji Metode Strut and Tie Model (a) Denah Penulangan Tarik Pile Cap Metode Strut and Tie Model; (b) Denah Penulangan Susut dan Suhu Pile Cap Metode Strut and Tie Model; (c) Potongan Penulangan Pile Cap Metode Strut and Tie Model

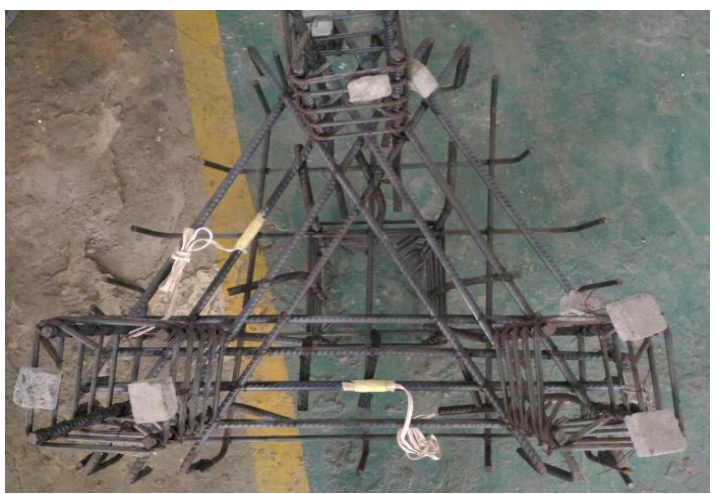

Gambar 3. Perakitan Baja Tulangan Metode Strur and Tie Model

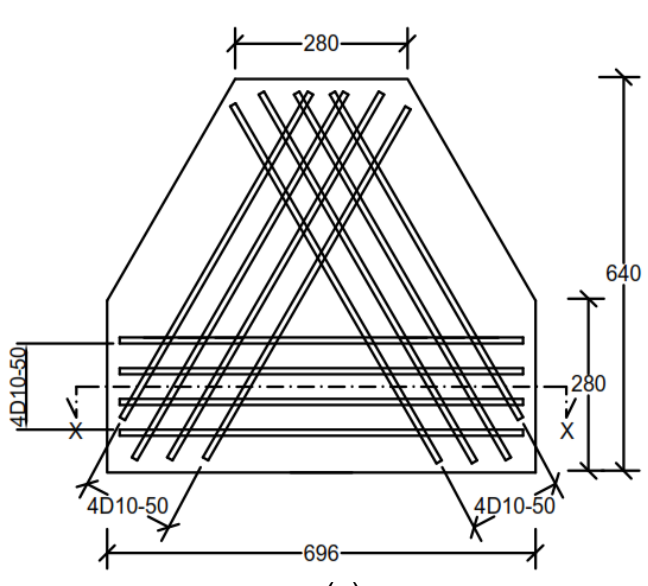

(a)

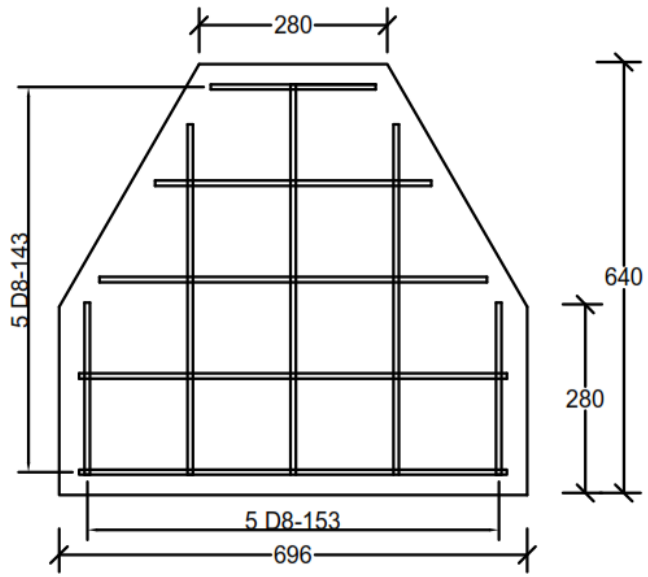

(b) 

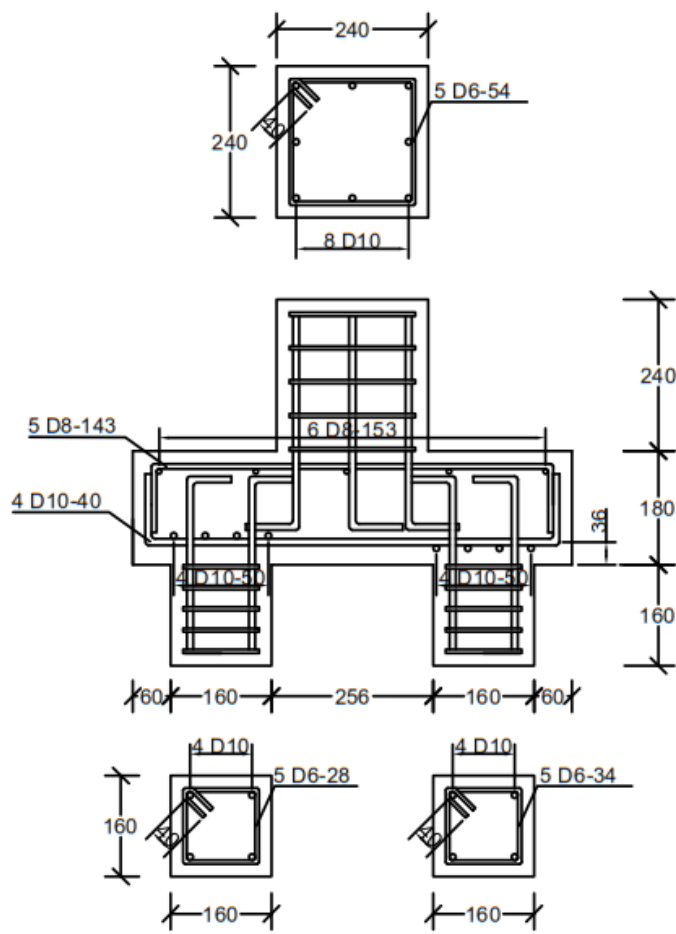

(c)

Gambar 4. Detail Benda Uji Metode Konvensional (a) Denah Penulangan Tarik Pile Cap Metode Konvensional; (b) Denah Penulangan Susut dan Suhu Pile Cap Metode Konvensional; (c) Potongan Penulangan Pile Cap Metode Konvensional

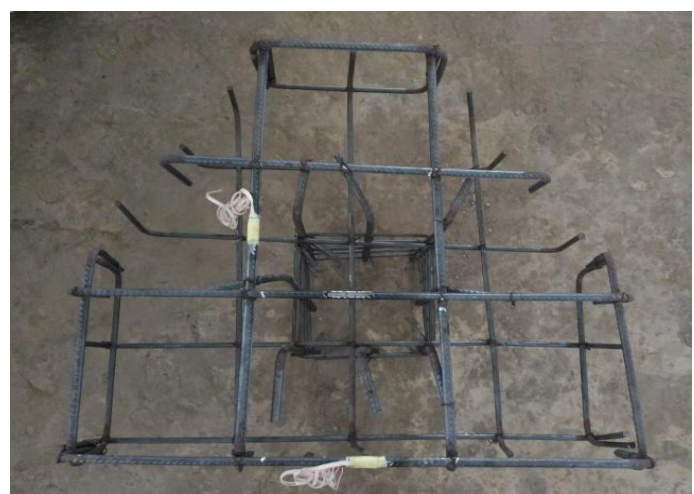

Gambar 5. Perakitan Baja Tulangan Metode Konvensional

Pada pembuatan benda uji terdapat beberapa tahapan antara lain sebagai berikut : pembuatan bekisting, pemotongan dan perangkaian baja tulangan, pemasangan strain gauge, pemeriksaan nilai slump, pembuatan silinder beton, dan pengecoran. Perawatan benda uji dilakukan dengan menutup benda uji menggunakan karung goni dan menyirami selama 28 hari. Kemudian dilakukan pengecatan dan meshing untuk memudahkan dalam pengamatan pola retak.

Setelah benda uji selesai dibuat maka dilakukan pengujian untuk mengetahui pola retak, kapasitas beban pada saat retak pertama, dan lebar retak yang terjadi pada benda uji. Adapun flowchart pengujian dan setting up alat pengujian akan dijelaskan pada Gambar 6 dan 7. 
Eksperimen pada Struktur ... (Maulana/ hal 31-43)

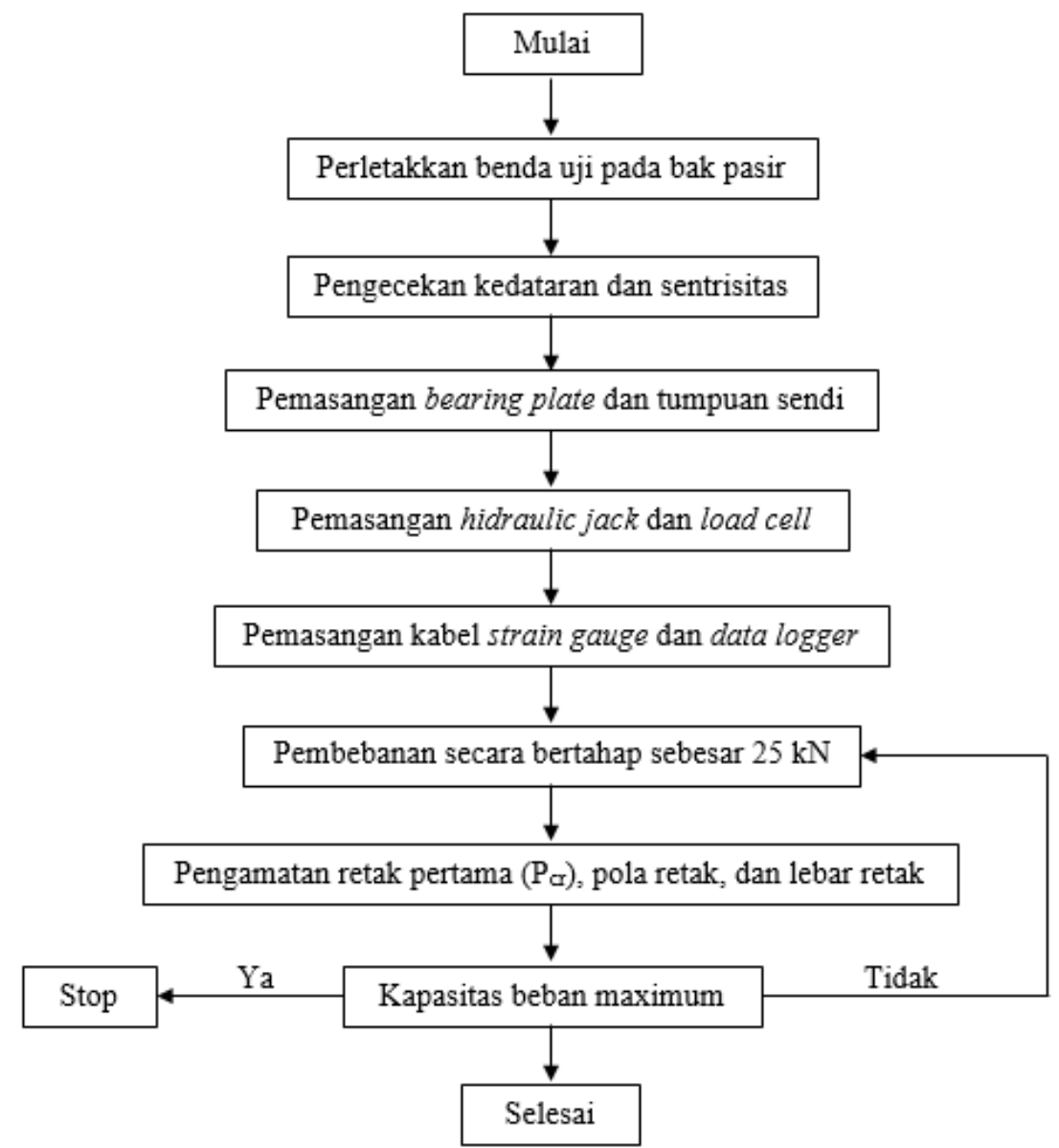

Gambar 6. Flowchart Pengujian

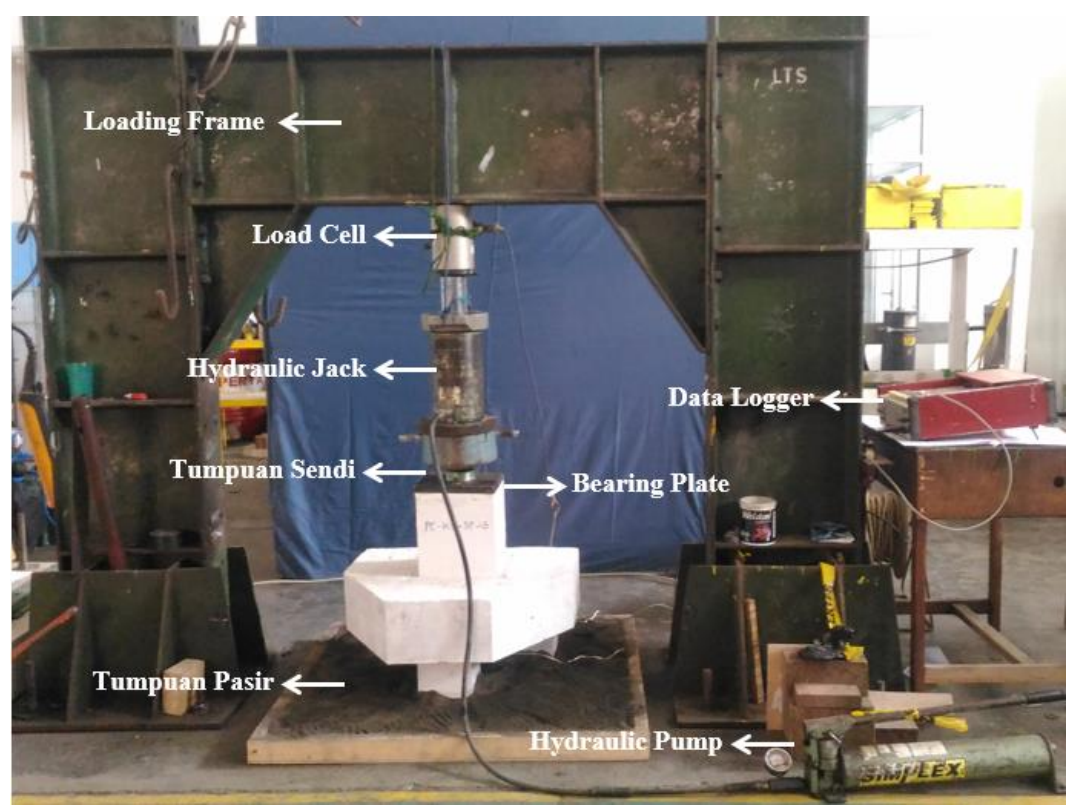

Gambar 7. Setting-up Alat Pengujian

\section{HASIL DAN PEMBAHASAN}

Sebelum dilakukan pengujian terhadap benda uji, terlebih dahulu dilakukan pengujian silinder beton setelah berumur 28 hari untuk mengetahui kapasitas kuat tekan 
Eksperimen pada Struktur ... (Maulana/ hal 31-43)

beton yang digunakan untuk membuat benda uji. Namun sebelum dilakukan pengujian kuat tekan beton, silinder beton tersebut harus dilakukan perawatan dengan cara direndam pada bak air. Jumlah silinder beton yang akan diuji sebanyak 4 buah dengan kuat tekan rencana sebesar K325 atau setara dengan $f_{c}$ ' sebesar 27,5 MPa. Adapun hasil pengujian kuat tekan beton dapat dilihat dalam Tabel 1.

Tabel 1. Hasil Pengujian Kuat Tekan Beton

\begin{tabular}{ccc}
\hline Benda Uji & $\begin{array}{c}\text { Beban Maksimal } \\
(\mathbf{k N})\end{array}$ & $\begin{array}{c}\text { Kuat Tekan }\left(\boldsymbol{f}_{c}{ }^{\prime}\right) \\
(\mathbf{M P a})\end{array}$ \\
\hline 1 & 480 & 27,59 \\
2 & 525 & 29,88 \\
3 & 530 & 30,17 \\
4 & 460 & 25,97 \\
\hline
\end{tabular}

Berdasarkan Tabel 1 dapat diketahui bahwa nilai rata-rata kuat tekan beton adalah 28,40 $\mathrm{MPa}$. Oleh karena itu terdapat kenaikan mutu beton sebesar 0,90 Mpa atau 3,28 \% dari kuat tekan rencana.

Setelah dilakukan pengujian pada semua benda uji maka didapatkan hasil pengujian berupa pengamatan pola retak, kapasitas beban pada saat retak pertama, dan lebar

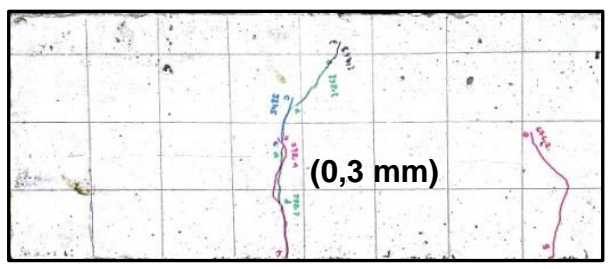

(a)

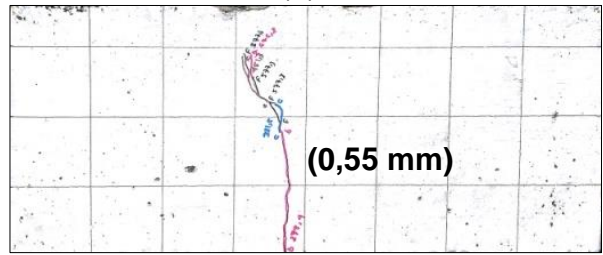

(b)

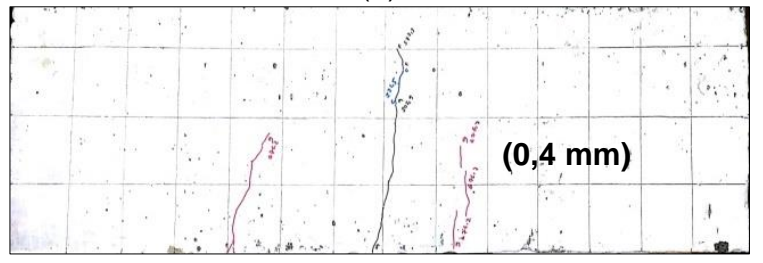

(c)

Gambar 8. Pola dan Lebar Retak Benda Uji PC-SS-3P-1 (a) Tampak Samping Kiri; (b) Tampak Samping Kanan

(c) Tampak Belakang; (d) Tampak Bawah retak pada akhir pengujian pada masingmasing benda uji.

Pengamatan pola retak pada pengujian ini dilakukan pada saat akhir pengujian dengan kapasitas beban sebesar 800 kN dikarenakan keterbatasan kapasitas alat. Adapun hasil pola retak pada masingmasing benda uji dapat dilihat pada Gambar 8 sampai Gambar 13.

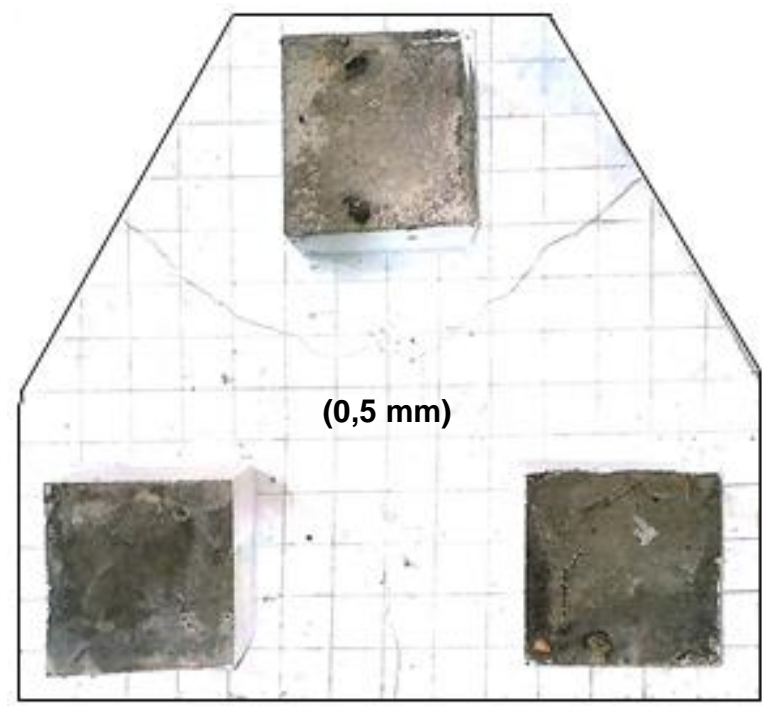

(d) 
Eksperimen pada Struktur ... (Maulana/ hal 31-43)

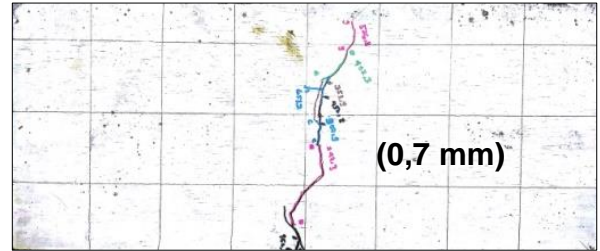

(a)

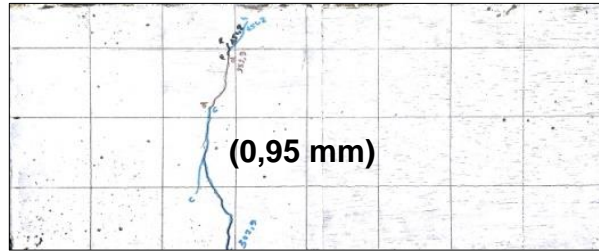

(b)

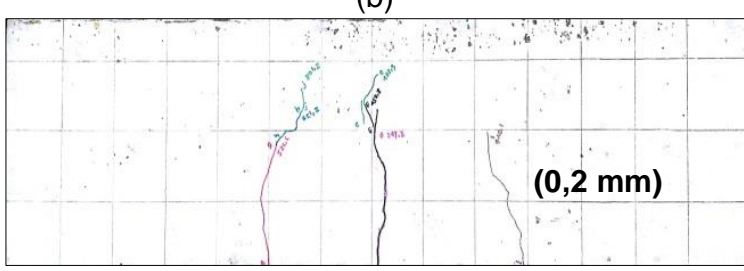

(c)

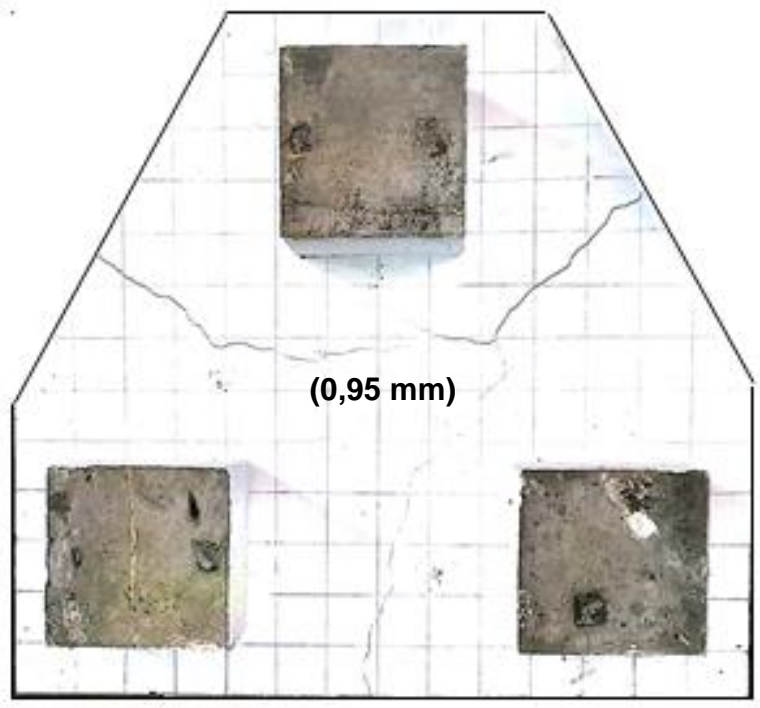

(d)

Gambar 9. Pola dan Lebar Retak Benda Uji PC-SS-3P-2 (a) Tampak Samping Kiri; (b) Tampak Samping Kanan; (c) Tampak Belakang; (d) Tampak Bawah

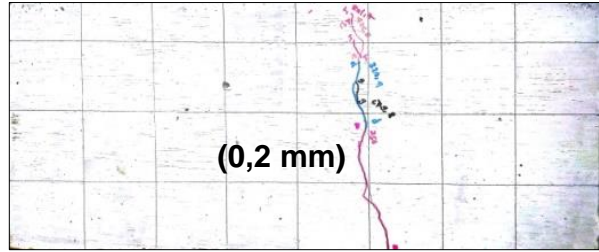

(a)

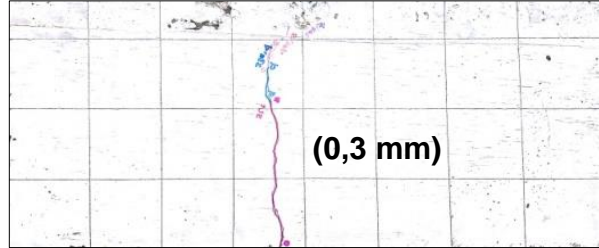

(b)

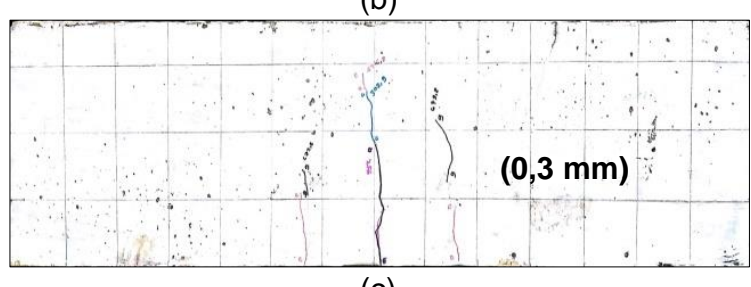

(c)

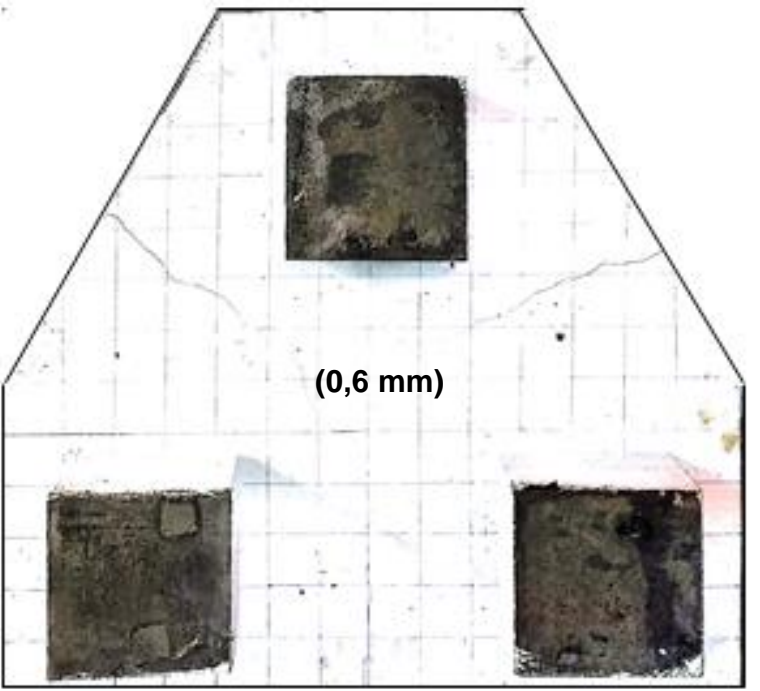

(d)

Gambar 10. Pola dan Lebar Retak Benda Uji PC-SS-3P-3 (a) Tampak Samping Kiri; (b) Tampak Samping Kanan; (c) Tampak Belakang; (d) Tampak Bawah

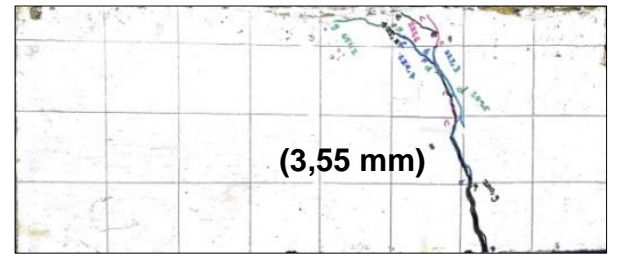

(a) 


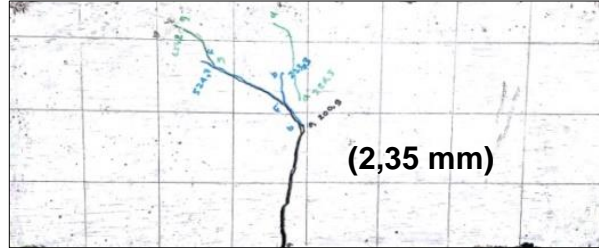

(b)

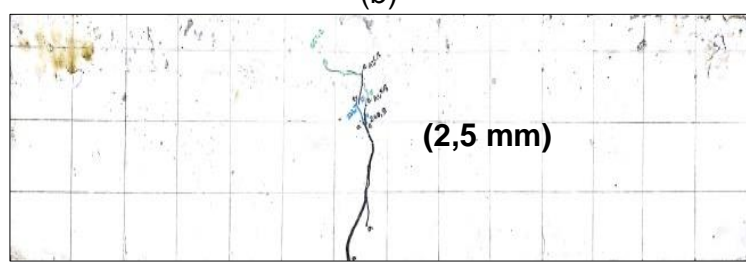

(c)

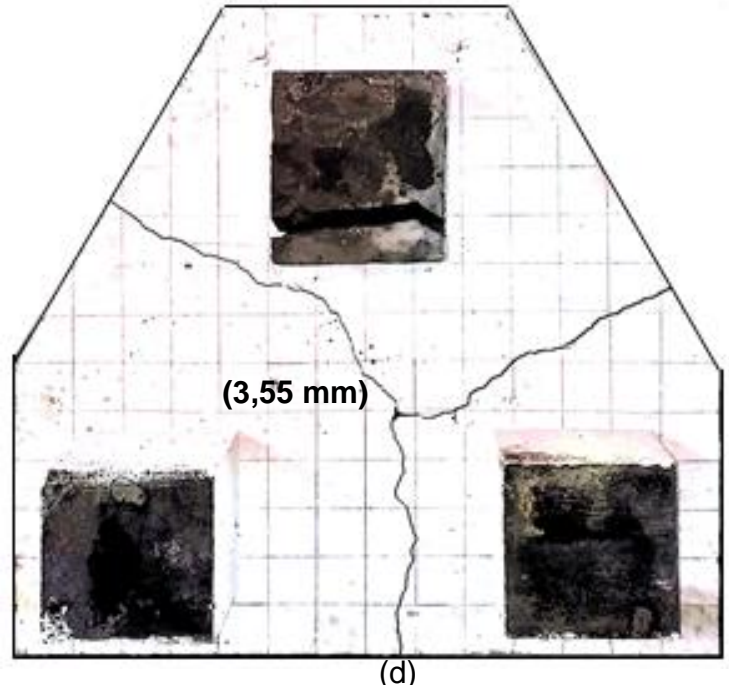

(d)

Gambar 11. Pola dan Lebar Retak Benda Uji PC-KS-3P-1 (a) Tampak Samping Kiri; (b) Tampak Samping Kanan; (c) Tampak Belakang; (d) Tampak Bawah

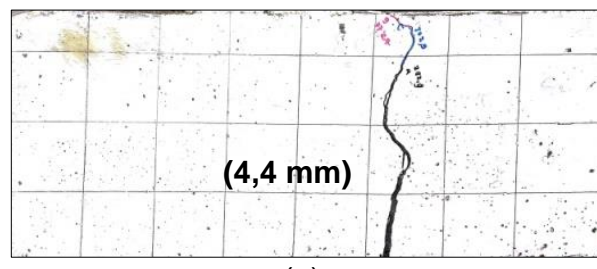

(a)

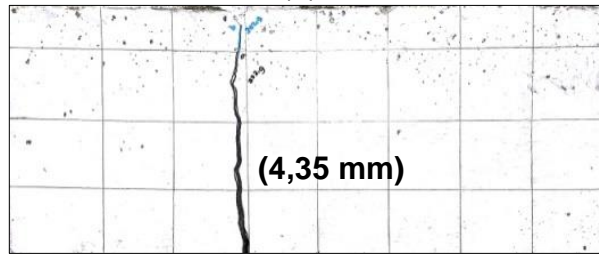

(b)

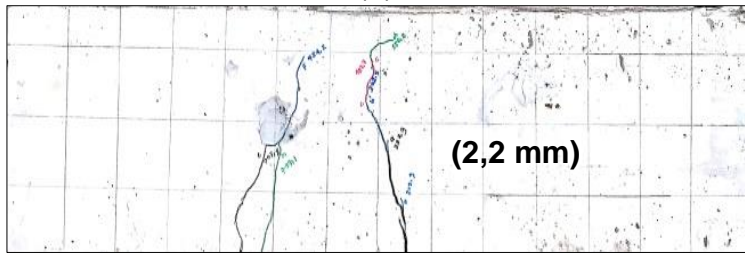

(c)

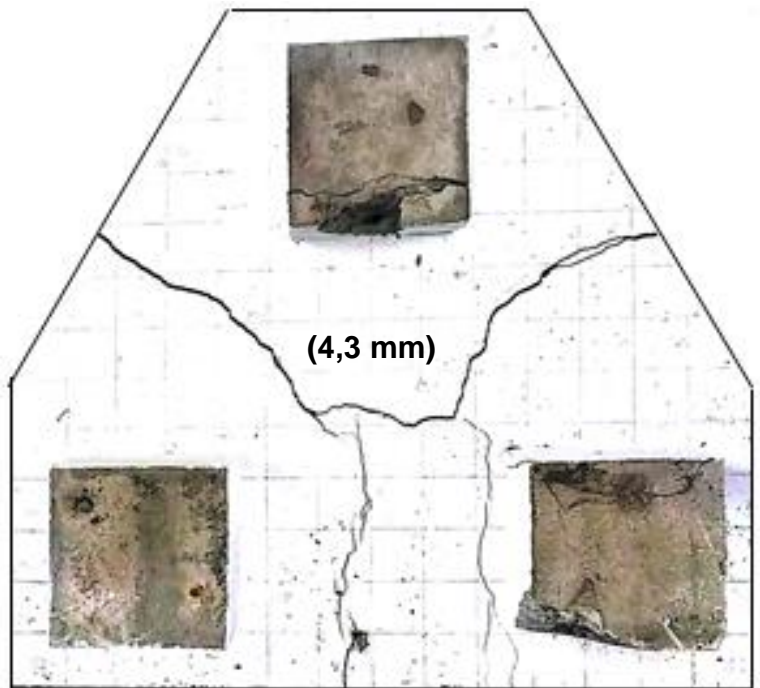

(d)

Gambar 12. Pola dan Lebar Retak Benda Uji PC-KS-3P-2 (a) Tampak Samping Kiri; (b) Tampak Samping Kanan; (c) Tampak Belakang; (d) Tampak Bawah

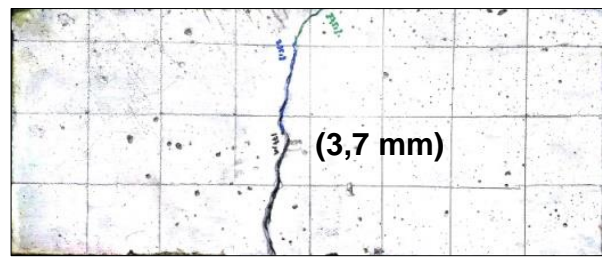

(a)

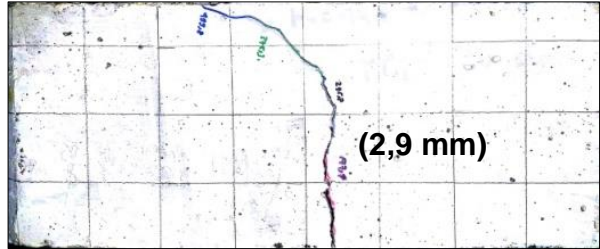

(b) 


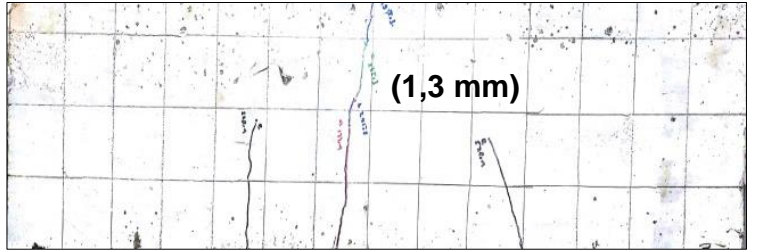

(c)

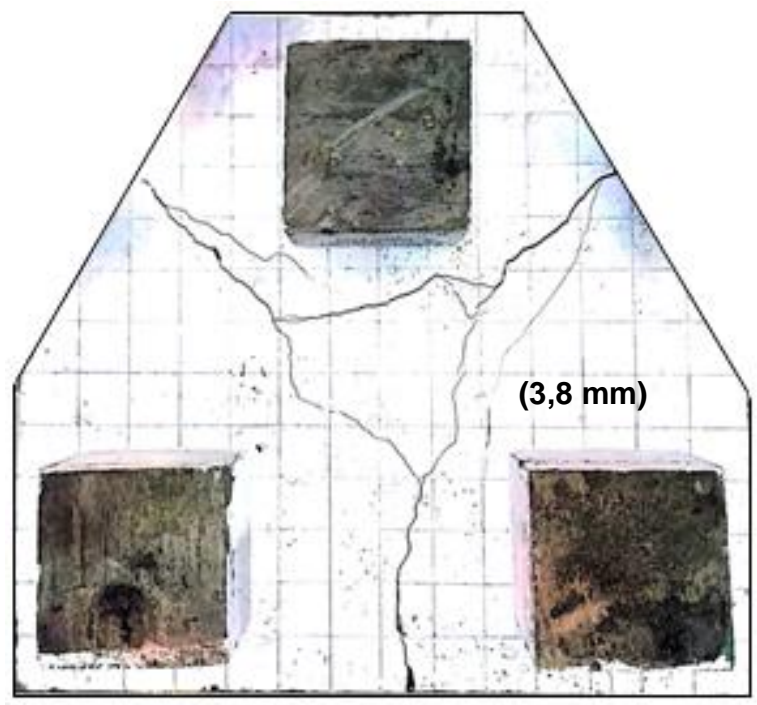

(d)

Gambar 13. Pola dan Lebar Retak Benda Uji PC-KS-3P-3 (a) Tampak Samping Kiri; (b) Tampak Samping Kanan; (c) Tampak Belakang; (d) Tampak Bawah

Berdasarkan Gambar 8 s.d 13 dapat diketahui bahwa semua benda uji berdasarkan metode strut and tie model maupun metode konvensional mempunyai pola retak yang hampir sama. Namun benda uji metode konvensional mempunyai pola retak yang lebih jelas dibandingkan dengan benda uji metode strut and tie model. Hal tersebut disebabkan karena pada akhir pengujian, benda uji metode konvensional mempunyai lebar retak yang lebih besar dibandingkan dengan metode strut and tie model sehingga lebih terlihat jelas.

Persebaran retak pada benda uji diawali dengan terjadinya retak pertama pada bidang bawah benda uji kemudian menyebar keluar pada bagian samping benda uji. Pola retak pada bagian bawah benda uji berbentuk diagonal memanjang dan menjalar diantara tiang, sehingga mengidentifikasikan terjadinya retak lentur (flexural crack). Untuk memperjelas tentang analisis pola retak tersebut dapat dilihat pada bagian samping dan belakang benda uji mengalami pola retak yang hampir tegak lurus dengan garis netral sehingga dapat dikatakan bahwa keseluruhan benda uji mengalami kegagalan lentur (flexural failure). Hal tersebut dikarenakan nilai dari momen lentur pada benda uji lebih besar dibandingkan dengan gaya geser.

Selain pengamatan pola retak, pada pengujian ini juga meninjau kapasitas beban yang mampu ditahan oleh benda uji pada saat terjadinya retak pertama. Retak tersebut diakibatkan oleh terlampauinya batas kuat tarik beton pada saat dilakukan pembebanan. Adapun kapasitas beban yang mampu ditahan oleh benda uji pada saat retak pertama akan dijelaskan pada Gambar 14 dan 15.

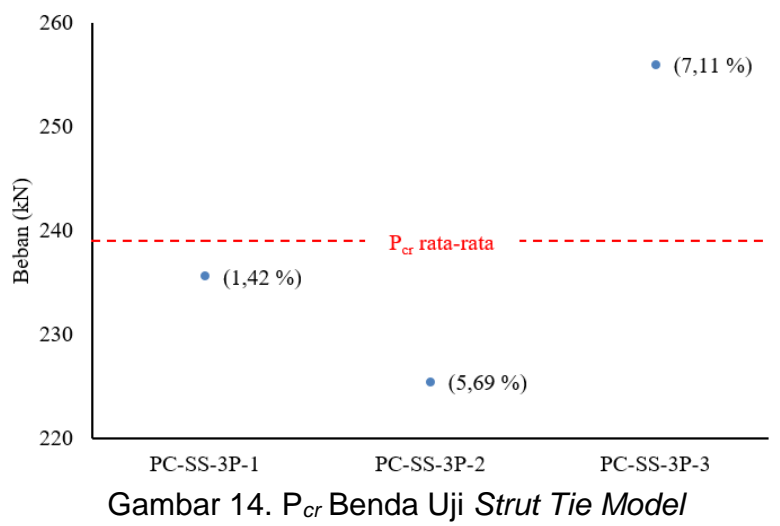




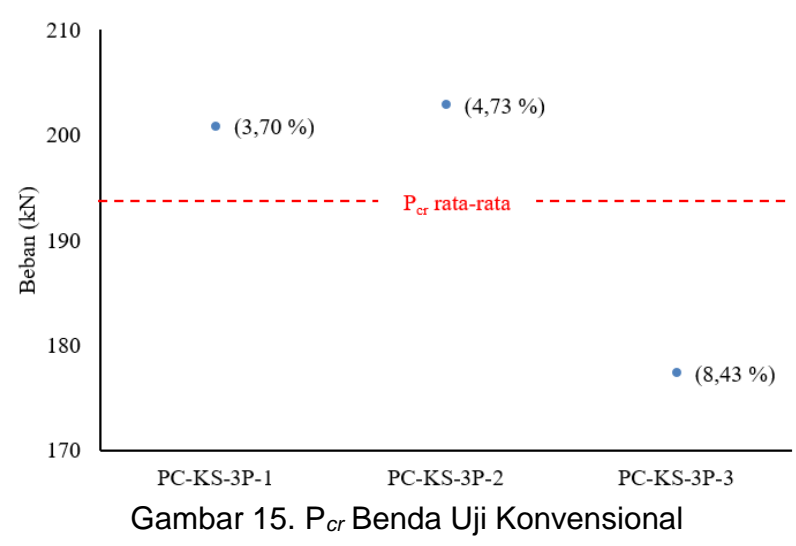

Berdasarkan Gambar 14 dapat diketahui bahwa rata-rata kapasitas beban pada saat retak pertama pada benda uji metode strut and tie model adalah 239,0 kN. Pada benda uji PC-SS-3P-3 mempunyai nilai kapasitas beban diatas rata-rata kapasitas beban sebesar $7,11 \%$, sedangkan benda uji PCSS-3P-1 dan PC-SS-3P-2 mempunyai nilai kapasitas beban dibawah rata-rata kapasitas beban sebesar 1,42\% dan 5,69 $\%$.

Pada Gambar 15 dapat diketahui bahwa rata-rata kapasitas beban pada saat retak pertama pada benda uji metode konvensional adalah 193,7 kN. Pada metode konvensional benda uji PC-KS-3P1 dan PC-KS-3P-2 mempunyai nilai kapasitas beban diatas rata-rata kapasitas beban sebesar 3,70 \% dan 4,73\%, sedangkan benda uji PC-KS-3P-3 mempunyai nilai kapasitas beban dibawah rata-rata kapasitas beban sebesar 8,43\%. Oleh karena itu dapat dikatakan bahwa metode strut and tie model mempunyai kapasitas beban 23,37\% lebih besar dibandingkan dengan metode konvensional pada saat retak pertama.

Selanjutnya akan dibahas lebar retak pada saat akhir pengujian. Pengujian lebar retak tersebut dilakukan pada akhir pengujian dengan kapasitas beban sebesar $800 \mathrm{kN}$. Hal tersebut dikarenakan keterbatasan kapasitas alat yang digunakan pada saat pengujian hanya mampu menahan sampai beban tersebut. Adapun hasil lebar retak pada benda uji dapat dilihat pada Gambar 16 dan 17.

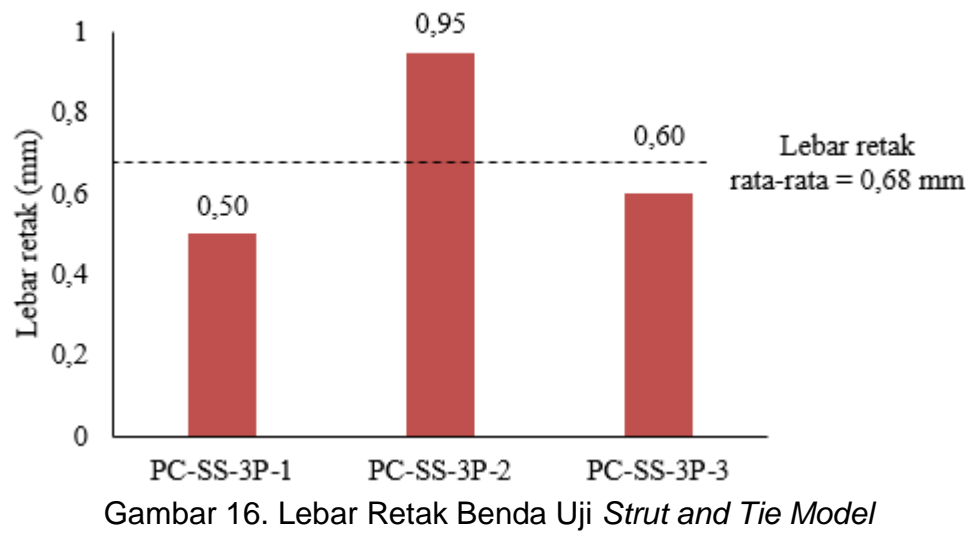




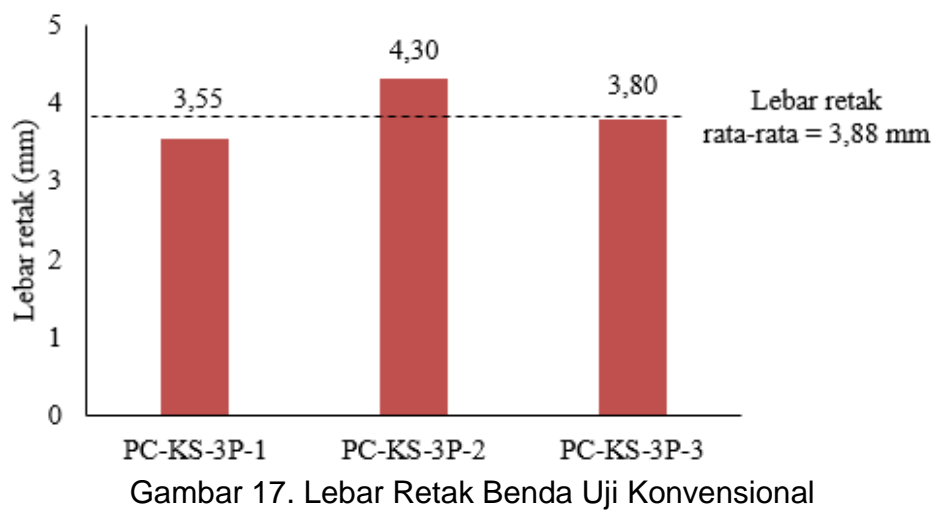

Berdasarkan Gambar 16 dapat diketahui bahwa rata-rata lebar retak pada bagian permukaan bawah benda uji metode strut and tie model adalah $0,68 \mathrm{~mm}$. Pada benda uji PC-SS-3P-2 mempunyai lebar retak diatas lebar retak rata-rata sebesar $39,02 \%$, sedangkan benda uji PC-SS-3P-1 dan PCSS-3P-3 mempunyai lebar retak dibawah lebar retak rata-rata berturut-turut sebesar $26,83 \%$ dan $12,20 \%$.

Pada Gambar 17 dapat diketahui bahwa rata-rata lebar retak pada bagian permukaan bawah benda uji metode konvensional adalah $3,88 \mathrm{~mm}$. Pada benda uji PC-KS-3P-2 mempunyai lebar retak diatas lebar retak rata-rata sebesar 10,73\%, sedangkan benda uji PC-KS-3P-1 dan PCKS-3P-3 mempunyai lebar retak dibawah lebar retak rata-rata berturut-turut berturutturut sebesar $8,58 \%$ dan $2,15 \%$. Oleh karena itu dapat dikatakan bahwa metode strut and tie model mempunyai lebar retak yang lebih kecil dibandingkan dengan metode konvensional pada akhir pengujian. Perbebaan kapasitas beban pada saat terjadi retak pertama dan lebar retak pada akhir pengujian disebabkan karena penempatan baja tulangan lentur pada benda uji metode strut and tie model lebih sesuai dengan arah trajektori tegangan atau

\section{SIMPULAN}

Berdasarkan hasil dan pembahasan di atas dapat ditarik beberapa kesimpulan antara lain sebagai berikut: semua benda uji metode strut and tie model maupun metode konvensional mempunyai pola retak yang hampir sama yaitu retak lentur (flexural crack). Kemudian pada kondisi retak pertama $\left(P_{c r}\right)$ benda uji metode strut and tie aliran gaya-gaya yang bekerja pada benda uji, sehingga baja tulangan lentur dapat menerima distribusi beban dengan lebih efektif dikarenakan posisi baja tulangan sesuai dengan arah persebaran tegangan. Sedangkan penempatan baja tulangan lentur pada benda uji metode konvensional kurang sesuai dengan arah trajektori tegangan atau aliran gaya-gaya yang bekerja pada benda uji, sehingga baja tulangan lentur tidak bisa dengan langsung menerima distribusi beban dikarenakan posisi baja tulangan lentur tidak sesuai dengan arah persebaran tegangan sehingga perlu dilakukan distribusi arah tegangan terlebih dahulu agar sesuai dengan posisi dan arah baja tulangan lentur. Kejadian tersebut menyebabkan beton pada metode konvensional mengalami retak pertama lebih awal dan terjadi penambahan lebar retak yang lebih besar dibandingkan dengan metode strut and tie model. Besarnya kapasitas beban pada saat terjadi retak pertama dan lebar retak pada akhir pengujian mengindikasikan besarnya kekakuan pada benda uji tersebut. Oleh karena itu dapat dikatakan bahwa benda uji metode strut and tie model mempunyai kekakuan yang lebih besar dibandingkan dengan metode konvensional.

model mempunyai kapasitas beban 23,37 $\%$ lebih besar dibandingkan dengan metode konvensional. Selanjutnya pada akhir pengujian dengan kapasitas beban $800 \mathrm{kN}$ benda uji metode strut and tie model mempunyai lebar retak yang lebih kecil dibandingkan dengan metode konvensional. Berdasarkan kondisi retak 
pertama $\left(P_{c r}\right)$ dan lebar retak pada akhir pengujian dapat disimpulkan bahwa benda uji metode strut and tie model mempunyai

\section{DAFTAR RUJUKAN}

Delalibera, R.G. dan Giongo, J.S., 2008. Deformations in The Strut of Two Pile Caps. Ibracon Structures and Materials Journal Vol. 1 No. 2 Pp. 121 -157 June 2008.

Hardjasaputra, H. dan Tumilar, S., 2002. Model Penunjang dan Pengikat (Strut and Tie Model) pada Perancangan Struktur Beton. Jakarta : Universitas Pelita Harapan Press.

Hardjasaputra, H., 2016. Perancangan Beton Struktural Berdasarkan Model Strat dan Pengikat (Strut and Tie Model) SNI 2847 - 2013. Jakarta : Jurusan Teknik Sipil Universitas Pelita Harapan.

Raj, A. dan Airin, M.G., 2017. Experimental and Analytical Investigation of Strut and Tie Model Method of Pile Cap. IOSR Journal of Mechanical and Civil Engineering (IOSR-JMCE) Pp. 30-35 2017.

Schlaich, J., and Schafer, K., 1984, 1989, 1993. Konstruiren in Stahlbetonbau. Berlin-Munich : Beton Kalender, Wilhelm Ernst\&Sohn.

Schlaich, J., Schafer, K. and Jennewin, M., 1987. Toward a Consistent Design of Structural Concrete. Journal of the Prestress Vol. 32 No.3 May - June 1987.

Shah, A., Haq, E., dan Khan, S., 2011. Analysis and Design of Disturbed Regions in Concrete Structures. Journal of Science Direct Procedia Engineering 14 Pp. 3317-3324 2011.

SNI 2847 : 2013, 2013. Persyaratan Beton Struktural untuk Bangunan Gedung. Jakarta : Badan Standarisasi Nasional.

Suhendro, B. 2000. Teori Model Struktur dan Teknik Eksperimental. Yogyakarta: Beta Offset. kekakuan yang lebih besar dibandingkan dengan metode konvensional. 